\title{
Ordinary People Doing Extraordinary Things: Responses to Stigmatization in Comparative Perspective
}

\section{Citation}

Lamont, Michèle and Nissim Mizrachi. 2011. Ordinary people doing extraordinary things: responses to stigmatization in comparative perspective. Responses to Stigmatization in Comparative Perspectives: Brazil, Canada, Israel, France, South Africa, Sweden and The United States. Special Issue. Ethnic and Racial Studies 35(3): 365-381.

\section{Published Version}

doi:10.1080/01419870.2011.589528

\section{Permanent link}

http://nrs.harvard.edu/urn-3:HUL.InstRepos:10493697

\section{Terms of Use}

This article was downloaded from Harvard University's DASH repository, and is made available under the terms and conditions applicable to Open Access Policy Articles, as set forth at http:// nrs.harvard.edu/urn-3:HUL.InstRepos:dash.current.terms-of-use\#OAP

\section{Share Your Story}

The Harvard community has made this article openly available.

Please share how this access benefits you. Submit a story.

Accessibility 


\title{
Ordinary People Doing Extraordinary Things: \\ Responses to Stigmatization in Comparative Perspective
}

Michèle Lamont

and

Nissim Mizrachi

\begin{abstract}
This special issue offers a first systematic qualitative cross-national exploration of how diverse minority groups respond to stigmatization in a wide variety of contexts. This research is the culmination of a coordinated study of stigmatized groups in Brazil, Israel, and the United States, as well as of connected research projects conducted in Canada, France, South Africa, and Sweden. The issue sheds light on the range of destigmatization strategies ordinary people adopt in the course of their daily life. Articles analyze the cultural frames they mobilize to make sense of their experiences and to determine how to respond; how they negotiate and transform social and symbolic boundaries; and how responses are enabled and constrained by institutions, national ideologies, cultural repertoires, and contexts. The similarities and differences across sites provide points of departure for further systematic research, which is particularly needed in light of the challenges raised by multiculturalism and diversity for liberal democracy.
\end{abstract}

Keywords: racism, anti-racism, stigma, destigmatization, identity, national ideologies 


\section{Why this special issue? Why now?}

There is a growing body of social science research on how members of ethnoracially stigmatized groups understand and respond to stigmatization, exclusion, misrecognition, racism and discrimination. ${ }^{\mathrm{i}}$ Building on this literature, this special issue offers a panoramic view of how everyday responses to stigmatization contribute to the transformation of group boundaries across a range of national contexts. We present new research that broadens and consolidates an emerging theoretical agenda. This research is the culmination of a coordinated study of stigmatized groups in Brazil, Israel, and the United States, as well as of connected research projects conducted in other sites (Canada, France, South Africa, and Sweden).

Our point of departure is Goffman (1963), who shows how individuals with discredited or "spoiled" identities take on the responsibility of managing interaction to prevent discomfort in others while preserving their own sense of self-worth. Feelings of stigmatization can be routine or traumatic and triggered by specific events - just as racism can be perceived as ongoing or situation-specific. ${ }^{\mathrm{ii}}$

Everyday responses to stigmatization are here defined as the rhetorical and strategic tools deployed by individual members of stigmatized groups in reaction to perceived stigmatization, racism, and discrimination. ${ }^{\text {iii }}$ While psychologists have considered how individuals cope with various types of stigmas (Oyserman and Swim, 2001), ${ }^{\text {iv }}$ they do not consider how these responses are associated with broader social factors - particularly with racial formation (Omi and Winant, 1994) and the cultural repertoires that are variously available across contexts (Swidler, 1986; Lamont and Thévenot, 2000; Mizrachi, Drori and Anspach, 2007). This concern with how cultural 
and structural contexts enable and constrain individual and group responses is one of the distinctive features of our contribution. Moreover, while social psychologists tell us that individuals cope with discrimination by privileging their in-group as reference group (Crocker, Major and Steele, 1998), we move beyond intra-psychological processes to study inductively a broader range of responses to stigmatization, and their relative salience, in meaning-making. Moreover, we deepen the analysis by showing the importance of national contexts and national ideologies and definitions of the situation in shaping responses to stigmatization.

Simmel (1971), Weber (1978 [1956]), and countless others, told us that group formation is a fundamental social process. It involves closure and opportunity hoarding (Tilly, 1998), differentiation (Blau, 1977), network formation (McPherson and SmithLovin, 1987), and a number of other group processes (e.g., Fine, 1979). While recent research focuses on the origins of group boundaries and particularly the role of the state in their formation (Wimmer and Min, 2006), we are more concerned with how boundaries are accomplished through the unfolding of everyday interaction and the frames that ordinary people use, which interact with collective myths about the nation (Bouchard, 2009, Castoriadis,1987). Thus we consider how in various national contexts, defined by deferent histories of intergroup relations, collective myths, and sociodemographic profiles, ordinary people claim inclusion, affirm their distinctiveness, contest and denounce stereotyping and claim their rights in the face of discriminatory behavior and other more subtle slights to their sense of dignity.

Despite (and because of) an abundance of historical and sociological studies concerning resistance (for instance, the role of religion in fostering resilience among 
African-American women in the face of discrimination (Frederick, 2003) or politicization among young Palestinian citizens of Israel (Rabinowitz and Abu-Baker, 2005)), there is a need for more systematic and cumulative inquiry into responses to stigmatization. Following everyday experiences and everyday practices enables a fresh dialogue about society from the perspective of marginalized groups (Hooks, 1990; Harding, 1993; Stoetzler and Yuval-Davis, 2002). Shifting the discussion to everyday life makes it possible to go beyond a rigid approach to the binary distinction between public and private, and to analyze everyday practices of individuals as social sites for the transformation of social hierarchies. Choices made in everyday life form the politics of small things (Goldfarb, 2006; Herzog, 2009; also Mansbridge and Flascher, forthcoming). At various times they may clash with or reinforce group boundaries as defined by public policies or state sanctioned representations (e.g. the census - see Bail, 2008). Examining them more closely is essential for a more comprehensive understanding of the making and unmaking of group boundaries.

The time is ripe for the pursuit of these objectives. In the United States, the election of Barack Obama raised awareness concerning the transformation of stigmatized identities. Social scientists have asked whether this change signals a broadening of predominant definitions of cultural membership, as well as a heightened awareness of differentiation among blacks (opposing middle class and ghetto blacks) (e.g. Bobo and Charles, 2009; Kloppenberg, 2010; Sugrue, 2010). This election also became an important point of reference around the planet, as it triggered countless scholarly conversations and public debates about the place given to subordinated minority groups in national myths and political systems. It confirmed that the progress 
of African-Americans is an unavoidable point of reference for minority groups elsewhere. Thus, this watershed election provided the occasion to examine more closely the constitution of racial and ethnic identity and group membership in a global context to complement a growing literature on the comparative study of racism and antiracism. $^{v}$

\section{Shared Theoretical Background}

The papers included in this special issue share several points of departure. concerning racial identification and group formation: First, follow Jenkins (1996) on social identity, we understand the latter as resulting from both self-identification (e.g. what it means for African-Americans to belong to this group) and group categorization (the meaning given to this group by out-group members (also Cornell and Hartman, 1997). Hence, understanding responses to stigmatization requires considering the formation of collective identities: how "us" and "them" are mutually defined, and how individuals and groups engage in boundary work in responding to stigmatization, both in private (when they ruminate about past experiences and how to make sense of their experiences), and in public, when they interact with others while reacting to specific events or incidents. However, in contrast to Jenkins' earlier formulations, we are inspired not only by social psychology, but also by the growing literature in cultural sociology that considers cultural repertoires (the cultural "supply-side"), as well as the conditions that make it more likely that members of groups will draw on some rather than other strategies available in their cultural tool-kits in formulating their responses (e.g. Lamont, 1992). National contexts make various kinds of rhetorics more or less readily available to social actors (e.g. "market" versus "civil" rhetorics in France and 
the United States (Lamont and Thévenot, 2000)), as our comparative analyses of responses to stigmatization reveals. We explore whether and how references to such repertoires are present in working-class and middle-class destigmatization strategies.

Second, together with Todd (2005), Wimmer (2008), Brubaker (2009), and others, we are concerned not only with social identity but also with identification processes and the development of groupness. However, we are centrally concerned not only with cognition but also with the role of emotion (particularly anger, pain, pride and other feelings directly associated with identity management - see Archer 2000; Bail 2010; Collins, 2004, Summers-Effler, 2002). As will be evident to the reader, there are wide variations in the extent to which ethno-racial categories are consolidated and salient across contexts; these influence whether respondents will readily interpret their experience of intergroup relationships through ethno-racial or other lenses. We also connect the drawing of group boundaries to everyday morality (e.g. Lamont, 2000 and Sayer, 2005, in the case of class). We are concerned with the self and the extent to which ready-made racial and ethnic identities, as compared to other markers (gender, religion, class, or nationhood), are available for individuals when constructing their personal identity.

Third, we consider social identity and group formation in the context of state or national ideology and collective history. These operate as cultural structures that constrain and enable different views of the self (Giddens, 1984), including group identity. While other classical contributions to comparative race relations remain more exclusively focused on political ideology and state structures (e.g., Marx, 1998; Lieberman, 2005), or elite discourse (e.g. Van Dijk, 1993; Eyerman, 2002), ${ }^{\mathrm{vi}}$ some of 
the papers included in this issue (e.g. Mizrachi and Herzog, in this issue)) connect such ideologies to micro-level cultural orientations and actions of ordinary people, which continuously feed into the transformation of group boundaries. More specifically, we aim to connect the political level (definitions of the polity and of cultural membership) to individual strategies by showing how macro repertoires affect micro strategies in increasingly globalized contexts. In such settings, cultural referents such as the logic of rights, hip hop culture, the black power movement, and anti-Americanism are becoming more salient as tools for self-definition across national cases.

\section{Methodological and Conceptual Approaches}

Whether implicitly or explicitly, most of the papers included in this special issue embrace the methodological standpoint that the juxtaposition of cases and the use of an inductive, bottom-up approach can reveal unanticipated racial conceptualizations (Morning, 2004), and responses to stigmatization that would otherwise remain invisible. We also focus on national cases where intergroup boundaries are more or less porous, policed, or crossable, so as to consider the impact of the permeability of boundaries on responses - and eventually draw generalizations about the relationship between racial regime and anti-racist strategies (Lamont and Bail, 2005). Again, we show that some responses are more likely in some contexts than in others, being enabled by distinct cultural repertoires. For instance, Afro-Brazilians use the metaphor of "racial mixture" to affirm their national belonging by invoking blurred racial symbolic boundaries (Reis and Silva, this issue); and Mizrahi Jews contest discrimination in ways that do not threaten their position as legitimate members of the Israeli polity, drawing on and reinforcing a definition of group membership that is based on shared religion (Mizrachi 
and Herzog, this issue). These papers show how different cultural repertoires (e.g. the national myth of "racial mixture" in Brazil or the Zionist melting pot ideology in Israel) are mobilized by individuals to make claims concerning their moral worth, membership, and similarity (or even superiority) to majority group members. Finally, situating responses to stigmatization in various national contexts highlights the singularity of the American case, where the level of distrust toward the white majority is particularly high and where "confronting" is the majority response among African-Americans interviewed.

New developments in cognitive sociology, cultural anthropology, and cultural psychology (D'Andrade, 1995; DiMaggio, 1997; Schweder, Minow and Markus, 2002) have opened novel theoretical as well as methodological avenues for research. These have yet to fully penetrate research in the field of immigration, ethnicity, and citizenship. Too often this literature remains committed to the use of a broad concept of relatively coherent "ethnic culture" that downplay internal group differences, overlooks hybrid cultural practices, and emphasizes shared values transmitted by parents or national contexts. In contrast, cultural sociologists have proposed a range of analytical tools such as "repertoire," "symbolic boundaries," "frame," and "narrative," to capture with greater specificity a variety of cultural processes. These tools are being applied to the study of the role of culture in the reproduction of poverty (Harding, Lamont, and Small, 2010, Lamont and Small, 2008). They are also put to use in a number of more recent American studies concerning racial and ethnic identity (Patillo-McCoy, 1999; Small, 2004; Lacy, 2007; Morning, 2009; Warikoo; for a review, see Lamont, 1999; Skrentny, 2008). 
We locate responses to stigmatization within a broader general sociology of classification and folk understandings about equality, with how members of stigmatized groups understand their cultural specificity and differences, and their relative positioning in the world. Furthermore, we view boundary work, meaning-making and folk classification as relating to ordinary people's daily management of heterogeneity and similarity within and between groups. Analytical devices such as boundary work, commensuration, and orders of worth (Boltanski and Thévenot,1991; Espeland and Stevens, 1998; Lamont and Molnar,2002), can be mobilized to capture similarities and differences in how ordinary people think about universalism, difference, and particularism, among others.

\section{Intellectual and Social Significance}

The theoretical significance of the project lies beyond its contribution to the development of a general grounded theory of responses to stigmatization. It also contributes to several literatures by opening new vistas in the study of anti-racism. More specifically: 1) The philosophical literature on the politics of distribution and recognition (Taylor, 1994; Fraser and Honneth, 2003) and communautarism (Walzer, 1997; Sen, 1998) has considered neither how non-elite individuals from stigmatized groups cope with the challenge of creating equality, nor the place of universalism and multiculturalism (or particularism) in this process. ${ }^{\text {vii }}$ 2) Social scientists working on social movements, such as the American civil rights movement (McPherson, 1975; McAdam, Tarrow and Tilly, 2001), or worldwide nationalist movements and anti-racist NGOs (Omi, 1993) have yet to explore how the frames promoted by social movements connect with the everyday anti-racist strategies of ordinary people (also Hobson, 2003). 
Our project will help to create this bridge, by looking beyond the confines of social movements to study recognition struggles in the context of "boundary-making activities" (also Wimmer, 2008); 3) While the literature on anti-racism is undergoing a shift from a philosophical focus (e.g., Taguieff, 1991) to a focus on anti-racist practices (e.g., Lentin, 2004), recent scholarship has established that states widely vary in their “culturally responsive policies" toward minority groups. Such policies apparently affect the extent to which groups direct their efforts toward specific institutions when claiming recognition and rights (Modood, 1997; Kymlicka, 2004). We also contribute to the study of cultural citizenship ${ }^{\text {viii }}$ and citizenship regimes ${ }^{\text {ix }}$ in connection with models of inclusion.

\section{Contributions}

Taken together, the studies in this issue provide a systematic analysis of how minority groups cope with stigma in a variety of national contexts. We now frame each of these papers to provide a wider and more integrative account of what they teach us about group identity formation and responses to stigmatization.

\section{A Bottom-up Comparison of Responses to Stigmatization}

At the center of this special issue is a three-way parallel comparison of responses to stigmatization strategies among members of ethnoracial minority groups in Brazil, Israel, and the United States. These three cases were selected to maximize the differences in perceived discrimination across cases, the latter being an indicator of the strength or permeability of boundaries across national contexts. The selection was based on a comparison by Lamont and Bail (2005) of the relative strength of social boundaries in various realms (labor market, spatial segregation, etc) as well as that of symbolic 
boundaries (pertaining to collective identity) across half a dozen countries. We hypothesized that overall, perceived discrimination, and by extension, the range and salience of anti-racist strategies, would be greater for Muslim Palestinian citizens of Israel than for Negros in Brazil, for whom interracial sociability and interracial sexual relationships are relatively frequent. We viewed the American case as an intermediary one, one where racism would be very salient, but also one where intergroup boundaries would be weaker than in Israel, with different patterns of responses.

The papers on these three national cases that are included in this issue are not explicitly comparative - the comparison is fleshed out in a collective book in preparation. However, each was developed against the background of the other cases. When read against each other, these cases provide a diverse panorama of responses to stigma as well as an understanding of how these are shaped by the position of the various groups in the national historical narratives. ${ }^{\mathrm{x}}$

The issue also includes papers that concern other cases, which together broaden even further our understanding of responses to stigmatization. These responses concern, for example, how some Middle-Eastern immigrants change their names to increase their integration in Sweden (Bursell in this issue); and how Afro-Caribbeans who live in France understand the place of slavery in French history, which influences their definition of their membership under a French republicanism that continues to deter acknowledgment of racial discrimination (Fleming in this issue). Both cases illuminate aspects of incorporation that remain invisible when observed through an assimilationist model --- including a form of pragmatic assimilation in Sweden. Moreover, we consider how structural constraints, global forces, cultural repertoires, 
and macro-level forces constrain responses to stigmatization (Mizrachi, Drori and Anspach, 2007). Conversely, Fleming, Lamont and Welburn (in this issue) document the relative salience of "confronting" and "deflating conflict" as responses to stigmatization and consider some of the meanings associated with these approaches, drawing on the tools of cultural sociology.

\section{Stigma and Misrecognition across Cultural Contexts}

In all the sites studied, members of stigmatized groups appeared to confront the tension between the emotional outcomes resulting from stigmatization (anger, pain, feelings of worthlessness, humiliation, loss of dignity, and so forth) on the one hand, and the need to gain recognition as an individual and a member of a group on the other. Their responses include individual and collective strategies. Studying middle class and working men and women living in the New York suburbs, Fleming, Lamont and Welburn found that African-Americans obtain recognition and maintain dignity by changing the negative meanings associated with their group through "educating" the ignorant and managing the self so as to not confirm stereotypes and to protect oneself. Their individual strategies are constrained by definitions of the situation - what respondents believe is possible and doable given their needs and dependencies on resources. They are also enabled by a widely available repertoire concerning the pervasiveness and unfairness of American racism. Also concerned with individual strategies, Welburn and Pittman consider the paradox that while very attuned to discrimination and racism, African-Americans focus on "motivational factors" for individual achievement. They found that these explanations are in tension with their shared experience as victims of discrimination, which leads them to emphasize 
structural explanations for success - resulting in a dual consciousness that is fed by shared historical experiences as well as belief in the American dream.

Turning to an isolated small-town community in Northern Ontario Canada, Denis considers collective responses to stigmatization by drawing on extensive ethnographic evidence. "He studies relations between Aboriginal (First Nation and Métis) and non-Aboriginal (predominantly white working class) residents. He finds that the majority group (mostly Euro-Canadians) used a laissez-faire approach to retain the social distance between themselves and the region's stigmatized Native population. Denis explores how both sides used, or avoided using, racial markers in negotiations over utilization of public resources. Whereas white residents gingerly avoided the rhetorical use of overt racial markers, the Natives were less hesitant to do so when they found such comments to be strategically useful. By showing how a minority "stigmatizes the stigmatizers," Denis’s ethnography provides a dynamic account of responses to stigmatization that takes into consideration how such responses are shaped in interaction. .

In other sites, references to national identity are central to the cultural repertoires that respondents mobilize to anchor their responses to stigmatization. For example, as Mizrachi and Zawdu reveal, Ethiopian Jews in Israel, who are blacks phenotypically but Jews culturally, use the Zionist national narrative to neutralize the stigma associated with blackness. They define themselves as "just another" group of Jewish immigrants participating in the resurrection of the Jewish nation. In contrast to African-Americans, they frame their responses to stigma in a national- rather than a market-oriented discourse. Similarly, the paper by Mizrachi and Herzog compares the cases of the 
Ethiopian Jews with those of Mizrachi (Oriental Jews) and Palestinian citizens of Israel. It shows that Ethiopian and Mizrachi Jews alike deny stigmatization by mobilizing the state's melting pot ideology as a cultural tool. While Ethiopian Jews downplay their phenotypical stigmatization, Mizrachi Jews downplay the stigma attached to their ethnic and cultural origins, associated with their arrival from Arab countries and consequent low status. Unlike the two other groups from Israel mentioned, Mizrachi Jews have more leverage regarding their full integration into the dominant society based on their uncontested Jewishness. This contrasts strongly with Palestinian Arabs' responses to stigmatization. Positioned outside the national narrative and collective identity, Palestinian citizens of Israel seek to maintain their dignity as the "ultimate other" under the unique geo-political context of the ongoing violence and deep-seated animosity characterizing relationships between Arabs and Jews in the Middle East.

According to Silva and Reis, ordinary working- and middle-class Brazilians embrace "racial mixture," not as a national myth but as a cultural practice that allows racial boundaries to be contextualized rather than taken for granted. As a consequence, racial mixture plays a less exclusionary and less politically loaded cultural tool for achieving inclusion than does shared religion in Israel. If Brazilian respondents acknowledge the existence of racism and racial inequalities, they mobilize racial mixture to de-essentialize racial categorization as, for example, in the idea that all Brazilians are "a little black."

\section{Personal Recognition and Participatory Destigmatization Strategies}

"The management of self" across sites hinges on factors related to resources, whether national or economic. Middle Eastern immigrants in Sweden and Palestinian citizens of 
Israel seek to neutralize the more impermeable symbolic and social boundaries to participate in the greater society without sacrificing their bounded identities. And these two groups operate in entirely different socio-political environments.

Palestinian Arabs have a group identity that is in constant tension with their identity as non-Jews, on which hinges the collective myth of the Israeli nation, as well as their assumed identification with external enemies. Mizrachi and Herzog show that Israeli Arab responses to stigmatization often involve depoliticization of social difference and mobilization of Jewish members in their social network, an approach that blurrs the boundary between themselves and Jewish Israelis by referring to universal human traits. This strategy does not deny their ethno-religious identity, which remains explicit and firmly differentiated from that of the Jews. Alternatively, Bursell shows that in Sweden, Middle Eastern immigrants often seek to camouflage their collective identity in the public sphere by using pragmatic assimilation, a strategy involving changing a basic ethnic marker, their names. This strategy enables them to retain their collective identity in the private realm while simultaneously enlarging their chances of participation as equal members in the labor market. Recognition is thereby achieved by altering identification criteria, a strategy that would be inconceivable for Palestinian Arabs in Israel given the politically loaded group divisions.

\section{History, Collective Narratives and Place in Time}

The cases of Afro-Antilleans in France (Fleming) and Ethiopians in Israel (Mizrachi and Zawdu) illustrate the multiple roles of history and citizenship when responding to stigmatization. In both cases, the reframing of the history of the group provides a remedy for stigmatization. 
According to Mizrachi and Zawdu, the depictions by Ethiopian Jews of their historical experience and contemporary status is made compatible with the state's melting pot ideology: they affirm their citizenship and belonging in the Zionist state by making it comparable to that of other immigrant groups. They apply the Zionist national narrative when claiming the right to equal participation while neutralizing the stigma associated with their blackness in their daily lives. Although phenotype remains a strong stigmatizing marker, the meaning of blackness is filtered through a national ideology that defines the polity and the place of groups in it (including the place of stigmatized groups).

For her part, Fleming compares two groups of mnemonic entrepreneurs who offer alternative frames for making sense of blackness in France. Referring to their experience in France's Caribbean colonies, some Afro-Antillean activists interpret the history of slavery in a way that is compatible with French republicanism: they downplay racial domination and their racial identity but highlight the universalism central to civic ideology. They aim to "rehabilitate" the image of the black slave by demanding "symbolic reparations" from the state in the form of commemoration rituals and an official redefinition of slaves as "victims." Another, competing, group of black activists adopt a pan-African perspective and emphasize blackness and the traditional (African) geographic origins of former slaves when defining their place and meaning of blackness in contemporary France. They affirm the blackness of victims and stigmatize 'whites' as the oppressor. 
Finally, in her comparison of individual responses to racism in Brazil and South Africa, Silva reveals how ordinary people use history in their folk understandings of racism and remediation. She shows that varied explanations for racism (grounded in history and/or human nature) lead to different conclusions about remedies and possibilities for social change.

\section{Concluding Remarks}

We believe that this special issue provides a panoramic view of responses to stigmatization by ordinary people and offers a novel research agenda. As this introduction demonstrates, the contribution results from a shared conceptualization which animates our past work and our coordinated case studies. We extend the literature horizontally and vertically by combining a close analysis of daily responses to stigma and cross-national analysis. This is essential if we are to better understand the processes of making and unmaking group boundaries, which result not only of public policies and state action, but also from ordinary people doing extraordinary things. 


\section{Acknowledgements}

The idea for this collective project took shape when Michèle Lamont was a Fellow at the Center for Advanced Studies in the Behavioral Sciences in Palo Alto, where she benefitted from early conversations with Larry Bobo, Hazel Markus, Doug McAdam,

and Claude Steele. A first planning conference "Ethnoracism and the Transformation of Collective Identity" was held at Harvard University in February 2005, with the support of the Weatherhead Center for International Affairs, Harvard University. This event was an occasion to share our approach and receive feedback from Frederick Barth and Richard Jenkins, as well as from social scientists who have remained our privileged interlocutors since the inception of the project: Christopher Bail, Lisa Berkman, Prudence Carter, Maria Kefalas, Nancy Krieger, Peggy Levitt, Jane Mansbridge, Mica Pollock, Yehouda Shenhav, James Sidanius, Edward Telles, Jennifer Todd, David Williams, and Andreas Wimmer. The project also benefited from repeated interaction with fellows from the Successful Societies program of the Canadian Institute for Advanced Studies, and particularly with Gérard Bouchard, Jim Dunn, Leanne Son Hing, Peter Hall, Danielle Juteau, Daniel Keating, Will Kymlicka, Ron Levi, Bill Sewell and Ann Swidler. The articles included in this issue represented several years of coordinated research efforts, which numerous exchanges and annual meetings made possible by a genenous Weatherhead Initiative grant from the Weatherhed Center for International Affairs. These articles were presented first at a conference on "Responses to Discrimination and Racism: Comparative Perspectives" held at the Center for European Studies, Harvard University in April 2010. 
http://isites.harvard.edu/icb/icb.do?keyword=k68885\&pageid=icb.page332386\&pageCo $\underline{\text { ntentId=icb.pagecontent } 683496}$

On this occasion, we benefitted from remarks from Nancy Hill and William Julius Wilson, who commented on the conference as whole, from comments from others discussants (acknowledged in individual papers), as well as from those of other graduate student participants centrally involved in the project-- particularly Steven Brown, Nicole Hirsh, Anthony Jacks, and Jovonne Bickerstaff. Other aspects of the collaboration have been funded by the Canadian Institute for Advanced Studies, The Israeli Binational Science Foundation, the Van Leer Institute, and the Brazilian National Research Council (CNPq), the State of Rio de Janeiro Science Foundation (FAPERJ), and the National Funding Agency for Research and Development (FINEP). Finally, we thank Christopher Bail, Moa Bursell, Hanna Herzog, Riva Kastoryano, Nonna Mayer, Graziella Silva and Andreas Wimmer for their comments on this introduction, as well as the influential scholars who have dialogued with and influenced our project over the past several years: Richard Alba, Philomena Essed, Joe Feagin, Orlando Patterson, Patrick Simon, and Howard Winant. Finally, we thank Heather Latham for her technical assistance in the middle phase of this project, and Travis Clough for his assistance in the final phase.

\section{REFERENCES}

APTHEKER, HERBERT 1992 Anti-Racism in U.S. History: The First Two Hundred Years, Westport, CT: Greenwood Press BAIL, CHRISTOPHER A. 2008 'The Configuration of Symbolic Boundaries against Immigrants in Europe', American Sociolgical Review, vol. 73, no. 1, pp. 37-59 
BAIL, CHRISTOPHER A. 2011 'Terrified: Emotions and the Evolution of Symbolic Boundaries Towards Muslims, 2001-2008' Ph.D. Dissertation, Department of Sociology, Harvard University

BLAU, PETER 1970 'A Formal Theory of Differentiation in Organizations', American Sociological Review, vol. 35, no. 2, pp. 201-218

BOBO, Lawrence and CHARLES, CAMILLE 2009 'Race in the American Mind: From the Moynihan Report to the Obama Candidacy', Annals of the American Academy of Political and Social Science, vol. 621, no. January, pp. 243-259

BODEMANN, Y. MICHAL. \& YURDAKUL, GÖKÇE 2006 'Migration, Citizenship, Ethnos', New York, NY: Palgrave Macmillan

BOLTANSKI, LUC. \& THÉVENOT, LAURENT 1991 De la Justification. Les économies de la grandeur, Paris: Gallimard.

BOUCHARD, GÉRARD 2009 'Collective Imaginaries and Population Health', in Michèle Lamont and Peter Hall (eds), Successful Societies: How Institutions and Culture Affect Health, New York: Harvard University Press, pp. 169-200 BRUBAKER, ROGER 2009 'Ethnicity, Race, and Nationalism', Annual Review of Sociology, vol. 35, pp. 21-42

CASTORIADIS, CORNELIUS 1987 The Imaginary Institution of Society, London:

Polity Press

CLARK, RODNEY et al. 1999 'Racism as a Stressor for African Americans: A Biopsychosocial Model', American Psychologist, vol. 54, no. 10, pp. 805-816

COLLINS, RANDALL 2004 Interaction Ritual Chains, Princeton: Princeton University Press

CORNELL, STEPHEN and HARTMAN, DOUGLAS 1997 Ethnicity and Race. Making Identity in a Changing World, Thousand Oaks, CA: Pine Forge Press CROCKER, JENNIFER et al. 1998 'Social Stigma', in Daniel Gilbert et al. (eds) Handbook of Social Psychology, Boston, MA: McGraw-Hill

D'ANDRADE, ROY 1995 The Development of Cognitive Anthropology, Cambridge, UK: Cambridge University Press

DIMAGGIO, PAUL 1997 'Culture and Cognition', Annual Review of Sociology, vol. 23, pp. 263-87

ESPELAND, WENDY and STEVENS, MITCHELL 1998 'Commensuration as a Social Process', Annual Review of Sociology, vol. 24, pp. 313-43

ESSED, PHILOMENA 1991 Understanding Everyday Racism: An Interdisciplinary

Theory, London: Sage Publications

EYERMAN, RON 2002 Cultural Trauma: Slavery and the Formation of AfricanAmerican Identity, Cambridge: Cambridge University Press

FINE, GARY 1979 'Small Groups and Culture Creation', American Sociological Review, vol. 44, pp. 733-45

FRASER, NANCY \& HONNETH, AXEL 2003 Redistribution or Recognition? A Political-Philosophical Exchange, London: Verso

FREDERICK, MARLA 2003 Between Sundays: Black Women and Everyday Struggles of Faith, Berkeley: University of California Press 
FREDRICKSON, GEORGE 2001 'Race and Racism in Historical Perspective:

Comparing the United States, South Africa, and Brazil', in Charles Hamilton (ed.)

Beyond Racism: Race and Inequality In Brazil, South Africa, and the United States,

Boulder, CO: Lynne Rienner Publishers

GIDDENS, ANTHONY 1984 The Constitution of Society: Outline of Theory of

Structuration, Berkeley: University of California Press

GOFFMAN, ERVING 1963 Stigma, Englewood Cliffs, NJ: Prentice Hall

GOLDFARB, JEFFREY 2006 The Politics of Small Things: The Power of the

Powerless in Dark Times, Chicago: University of Chicago Press

HALL, PETER and LAMONT, MICHÈLE 2010 'Social Resilience in the Age of neo-

Liberalism', Presented at the meeting of the Successful Society Program, Toronto:

Canadian Institute for Advanced Research

HARDING, SANDRA 1993 'Rethinking Standpoint Epistemology: What is "Strong

Objectivity?", in Linda Alcoff and E. Potter (eds) Feminist Epistemologies, New York,

NY: Routledge

HERZOG, HANNA 2009 'Choice as Everyday Politics: Female Palestinian Citizens of

Israel in Mixed Cities', International Journal of Politics, Culture, and Society, vol. 22, pp. 5-21

HOBSON, BARBARA 2003 Recognition Struggles and Social Movements: Contested

Identities, Agency, and Power, Cambridge, UK: Cambridge University Press

HOOKS, BELL 1990 Yearning - Race, Gender, and Cultural Politics, Boston: South

End Press

JENKINS, RICHARD 1996 Social Identity, London: Routledge

JENSON, JANE and PHILLIPS, SUSAN 2002 'Redesigning the Canadian Citizenship

Regime: Remaking the Institutions of Representation', in CROUCH, COLIN et al. (eds)

Citizenship, Markets and the State, London: Oxford University Press

KLOPPENBERG, JAMES 2010 Reading Obama: Dreams, Hope, and the American

Political Tradition, Princeton: Princeton University Press

KYMLICKA, WILL 2004 'Culturally Responsive Policies', United Nations Health

Development Report, New York

LACY, KARYN 2007 Blue-Chip Black: Race, Class, and Status in the New Black

Middle Class, Berkeley, CA: University of California Press

LAMONT, MICHÈLE 1992 Money, Morals and Manners: The Culture of the French

and American Upper-Middle Class, Chicago, IL: University of Chicago Press

LAMONT, MICHÈLE and BAIL, CHRISTOPHER 2005 'Sur les frontièrs de la

rconnaissance. Les catégories internes et externes de l'identité collective', Revue

Europenne des Migrations Internationales, vol. 21, no. 2, pp. 6190

LAMONT, MICHÈLE. \& MOLNÁR, VIRÀG 2002 'Social Categorization and Group

Identification: How African-Americans Shape Their Collective Identity Through

Consumption', in Andrew McMeekin et al. (eds) Innovation by Demand: An

Interdisciplinary Approach to the Study of Demand and its Role in Innovation,

Manchester, UK: Manchester University Press

LAMONT, MICHÈLE and SMALL, MARIO 2008 'Culture Matters: The Role of

Culture in Explaining Poverty ', in David Harris and Ann Lin (eds) The Colors of

Poverty: Why Racial and Ethnic Disparities Persist, New York: Russel Sage

Foundation 
LAMONT, MICHÈLE. \& THÉVENOT, LAURENT 2000 'Rethinking Comparative Cultural Sociology: Repertoires of Evaluation in France and the United States', London: Cambridge University Press and Paris: Presses de la Maison des sciences de l'homme LENTIN, ALANA 2004 Racism and Anti-Racism in Europe, London: Pluto Press LINK, BRUCE and PHELAN, JO 2000 'Evaluating the Fundamental Cause Explanation for Social Disparities in Health', Handbook of Medical Sociology, pp. 3346

MANSBRIDGE, JANE and FLASTER, KATHERINE 2005. "Male Chauvinist, Feminist, Sexist, and Sexual Harrassment: Different Trajectories in Feminist Linguistic Innovation, American Speech, vol. 80, no. 3, pp. 256-279

MARX, ANTHONY 1998 Making Race and Nation: A Comparison of South Africa, the United States and Brazil, Cambridge, UK: Cambridge University Press

MCADAM, DOUG et al. 2001 Dynamics of Contention, New York, NY: Cambridge University Press

MCPHERSON, JAMES 1975 The Abolitionist Legacy: From Reconstruction to the $N A A C P$, Princeton, NJ: Princeton University Press

MCPHERSON, J. MILLER et al. 2006 'Social Isolation in America: Changes in Core Discussion Networks over Two Decades', American Sociological Review, vol. 71, no. 3, pp. 353-375

MIZRACHI, NISSIM et al. 2007 'Repertoires of Trust: The Practice of Trust in a Multinational Organization amid Political Conflict', American Sociological Review, vol. 72, pp. 143-165 MODOOD, TARIQ 1997 "Difference', Cultural Racism and Anti-racism', in Pninan werbner and Tariq Modood (eds) Debating Cultural Hybridity, London: Zed Books MORNING, ANN 2009 'Toward a Sociology of Racial Conceptualization for the 21st Century', Social Forces, vol. 87, no. 3, pp. 1167-1192

OMI, MICHAEL 1993 'The Los Angeles 'Race Riot' and Contemporary U.S. Politics', in Robert Gooding-Williams (ed.) In Reading Rodney King/Reading Urban Uprising, New York, NY: Routledge OMI, MICHAEL and WINANT, HOWARD 1994 Racial Formation In The United States: From The 1960s To The 1990s, New York and London: Routledge ONG, AIHWA 1996 'Cultural citizenship as subject-making. Immigrants negotiate racial and cultural boundaries in the United States', Current Anthropology, vol. 37, no. 5, pp. 737-62

OYSERMAN, DAPHNA and SWIM, JANET 2001 'Social Stigma: An Insider's View ', Journal of Social Issues, vol. 57, no. 1, pp. 1-14

PATILLO-MCCOY, MARY 1999 Black Picket Fences. Privilege and Peril among the Black Middle Class, Chicago, IL: University of Chicago Press

PINEL, ELIZABETH 1999 'Stigma Consciousness: The Psychological Legacy of Social Stereotypes', Journal of Personality and Social Psychology, vol. 76, no. 1, pp. $114-128$

POLLOCK, MICA 2008 Everyday Antiracism: Getting Real About Race, New York, NY: The New Press

RABINOWITZ, DAN and ABU-BAKER, KHAWLA 2005 Coffins on Our Shoulders: The Experience of the Palestinian Citizens in Israel, Berkeley: University of California Press 
RIVERA, LAUREN 2008 'Managing 'Spoiled' National Identity: War, Tourism and Memory in Croatia', American Sociological Review, vol. 73, pp. 613-634

SAGUY, ABIGAIL and WARD, ANNA 2011. 'Coming Out as Fat: Rethinking

Stigma', Social Psychology Quarterly

SAYER, ANDREW 2005 The Moral Significance of Class, New York, NY: Cambridge University Press

SCHWEDER, RICHARD et al. 2002 Engaging in Cultural Differences, New York, NY: Russell Sage Foundation

SEN, AMARTYA 1998 'Universal Truths: Human Rights and the Westernizing Illusion', Harvard International Review, vol. 20, no. 3, pp. 40-43

SIMMEL, GEORG 1971 'The Stranger', Individuality and Social Form, Chicago: University of Chicago Press

SKRENTNY, JOHN 2008 'Culture and Race/Ethnicity: Bolder, Deeper, and Broader', The ANNALS of the American Academy of Political and Social Science, vol. 619, no. 1, pp. 59-77

SMALL, MARIO 2004 Villa Victoria, Chicago, IL: University of Chicago Press SOMERS, MARGARET 2008 Genealogies of Citizenship, New York: Cambridge University Press

STOETZLER, MARCEL and YUVAL-DAVIS, NIRA 2002 'Standpoint/theory, Situated Knowledge and the Situated Imagination', Feminist Theory, vol. 3, no. 3, pp. 315-333

SUGRUE, THOMAS 2010 'Not Even Past: Barack Obama and the Burden of Race', Princeton: Princeton University Press

SUMMERS-EFFLER, ERIKA 2002 'The Micro Potential for Social Change: Emotion, Consciousness, and Social Movement Formation', Sociological Theory, vol. 20, pp. 2160

SWIDLER, ANN 1986 'Culture in Action: Symbols and Strategies', American Sociological Review, vol. 51, pp. 273-286

TAGUIEFF, PIERRE-ANDRÉ 1991 Face au racisme 1: les moyens d'agir, Paris: La Découverte

TAYLOR, CHARLES 1994 Reconciling the Solitudes: Essays on Canadian Federalism and Nationalism, Montreal: McGill-Queen's University Press

TILLY, CHARLES 1998 Durable Inequality, Berkeley: University of California Press TODD, JENNIFER 2005 'Social Transformation, Collective Categories, and Identity Change', Theory and Society, vol. 34, no. 4, pp. 429-63

VAN DIJK, TEUN 1993 Elite discourse and racism, Newbury Park, CA: Sage WALZER, MICHAEL 1997 On Toleration, New Haven: Yale University Press WARIKOO, NATASHA Forthcoming Balancing Acts: Youth Culture at School in the Global City, Berkeley: University of California Press

WEBER, MAX 1978 [1914] Economy and Society: An Outline of Interpretive Sociology, Berkeley, CA: University of California Press

-- 1978 [1956] Economy and Society, Berkeley, CA: University of California Press WILLIAMS, DAVID et al. 2008 'Racial/Ethnic Discrimination and Health: Findings from Community Studies', American Journal of Public Health, vol. 98, no. 1, pp. S29S37

WIMMER, ANDREAS 2008 'The Making and Unmaking of Ethnic Boundaries: A 
Multilevel Process Theory', American Journal of Sociology, vol. 113, no. 4, pp. 9701022

WIMMER, ANDREAS and MIN, BRIAN 2006 'From Empire to Nation-States.

Explaining Wars in the Modern World', American Sociological Review, vol. 71, no. 6, pp. 267-297

WODAK, RUTH 2001 'The Discourse-Historical Approach', in Ruth Wodak and M. Meyer (eds) Methods of Critical Discourse Analysis. London: Sage 
MICHELE LAMONT is Robert I Goldman Professor of European Studies and Professor of Sociology and African and African American Studies at Harvard University.

ADDRESS: Department of Sociology, Harvard University,33 Kirkland St. Cambridge MA 02138, USA. Email: mlamont@wjh.harvard.edu

NISSIM MIZRACHI is a member of the Senior Faculty, the Department of Sociology and Anthropology, Tel Aviv University, and a Research Fellow at the Van Leer Jerusalem Institute.

ADDRESS: Department of Department of Sociology and Anthropology, Tel Aviv University, Ramat Aviv, Israel 69400. Email: nissimm@ post.tau.ac.il

\footnotetext{
i We use the term "ethno-racial" to refer to groups that are discriminated against due to their phenotypical characteristics or ethnicity and their associated markers (such as expressive culture, religion, and language).

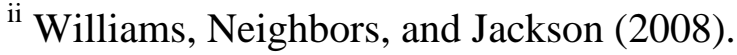

iii The notion of “everyday response to stigmatization" is inspired by Essed (1991)’s notion of everyday racism as “...integration of racism into everyday situations through practices that activate underlying power relations" (50). It also expands on Aptheker (1992)'s definition of anti-racism, as rhetoric aimed at disproving racial inferiority. For a discussion of everyday anti-racism, see Pollock (2008).

iv See Pinel (1999) on "stigma consciousness," and Clark et al. (1999) on how minority groups cope psychologically with the "perceived stressor" of racism and prejudice. See Link and Phelan (2000) for a broader review of the literature on stigma, which is most often concerned with the stigma of "stressors" such as mental illness and physical handicaps, and their impact on health.
} 
${ }^{\mathrm{v}}$ See Fredrickson (2001) on racism in South Africa and Brazil, Marx (1998) on US, Brazil and South Africa, Lentin (2004) on comparative antiracism in Europe, and others.

${ }^{\mathrm{vi}}$ Space limitation precludes a comparison of our approach with the influential critical discourse analysis approach to racism (e.g. Wodak 2001).

${ }^{\text {vii }}$ While Bourdieu discussion recognition and misrecognition in terms of struggle for legitimacy and symbolic violence in fields, we are more concerned with the moral aspects of recognition, i.e. the assertion of human worth and dignity (see Honneth 1995).

viii Ong (1996); Bodemann and Yurdakul (2006).

${ }^{\text {ix }}$ Jenson and Phillips (2002).

x See Rivera (2009) and Saguy (2010) for complementary studies of responses to stigma. 